УДК 334.75

DOI: https://doi.org/10.26642/jen-2019-4(90)-3-7

\author{
К.В. Авдалян, аспірант \\ ДВНЗ «Переяслав-Хмельницький \\ державний педагогічний університет імені Григорія Сковороди»
}

\title{
Сучасні тенденції об’сднання підприємств в економіці України
}

\author{
(Представлено: д.е.н., проф. Лисещький А.С.)
}

У статті розглянуто основні організаційно-правові форми об'єднань підприємств у сфері реального сектору економіки, створення яких забезпечує його учасників стратегічними перевагами над конкурентами та дозволяє координувати діяльність всіх ланок технологічного ланияюга та залучати великі фінансові ресурси. Досліджено історичний аспект становлення та розвитку об'єднань підприємств, иче дало змогу виокремити шість етапів розвитку об'єднань підприємств. Доведено, що світова економіка побудована на взаємодї транснаціональних корпорацій. Висвітлено передумови виникнення, розвиток та становлення транснаціональних корпорацій, їхній вплив на світову економіку. Роз'яснено основні ключові аспекти, щзо стосуються транснаціональних корпорацій: особливості управління, діяльність транснаціональних корпоращій, вплив на економічну діяльність країни, кількісні показники. Узагальнено основні фактори, які впливають на суб'єктів господарювання до укрупнення бізнесу. Проаналізовано динаміку кількості різних форм господарського об'єднання підприємств, які зареєстровані в Сдиному державному реєстрі підприємств та організацій Украйни, що дало змогу встановити, щьо збільшення кількості об’єднань підприємств спостерігається за такою організаційно-правовою формою, як асоціація.

Ключові слова: об’єднання підприємств; транснаціональні корпорації; асоціація; глобальна економіка; ринкова економіка.

Постановка проблеми. В сучасних умовах господарювання протягом останніх років поодинокі компанії чи підприємства дуже часто не мають можливості здійснювати фінансове забезпечення своєї виробничо-господарської діяльності й опиняються серед неплатоспроможних, тому об'єднують свою діяльність в одне ціле для вирішення спільних питань. В останні роки спостерігається тенденція щодо збільшення кількості підприємств, які об’єднують власні виробничі потужності, змінюють структуру взаємодії, тим самим створюючи загрозу утворення монополій як національного, так і світового рівня. Основною причиною утворення об’єднань підприємств є координація виробничої, наукової та іншої господарської діяльності з метою вирішення економічних та соціальних питань задля убезпечення себе від ймовірного стану неплатоспроможності.

Аналіз останніх досліджень та публікацій. Актуальність створення та функціонування об'єднань підприємств вивчали такі науковці, як С.О. Баркалов, І.В. Бейцун, О.М. Вінник, С.М. Грудницька, О.С. Гудзь, О.Р. Кібенко, О.М. Кириленко, О.М. Островська В.Н. Петрина, В.С. Щербина та ін. Не залишилась поза увагою дана тема й серед іноземних вчених, таких як Джоел Дж. Сiегел (Joel G. Ciegel) та Джей К. Шим (Jae K. Shim), Крістофер Ноубс (Christifer Nobes), Б.Г. Федоров та ін.

Викладення основного матеріалу. Розвиток інтеграційних процесів у світі призвів до утворення великих об'єднань підприємств, які вагомо впливають на економічну діяльність країн, в яких вони функціонують. Розвиток об'єднань підприємств постійно знаходиться під впливом економічного та політичного клімату. Історично ступінь діяльності та цілі бізнесу - це об'єкт змін. Можна виокремити шість етапів розвитку об'єднання підприємств (табл. 1).

Інтернаціональний характер угод придбання та злиття підприємств призводить до того що дані процеси починають поширюватися і на території України. Вітчизняні підприємства є не лише об'єктами таких об’єднань, а також і ініціаторами. Практика придбання діючих підприємств ще не отримала в Україні такого ж широкого розповсюдження, як в країнах з розвиненою ринковою економікою, але все ж таки набуває поширення невеликими темпами.

Сьогодні вся світова економіка побудована на взаємодії транснаціональних корпорацій. Транснаціональна корпорація - це компанія, яка має представництво у двох країнах чи більше незалежно від їхнього юридичного статусу у сфері діяльності. Вона здійснює загальне управління з єдиного центру, а окремі іiі одиниці пов'язані структурою власності або іншим способом. Центральний офіс, або материнська компанія, значно впливає на діяльність через контроль над знаннями, ресурсами, відповідальністю тощо. Є також орієнтовні кількісні показники для діючих транснаціональних корпорацій. Річний обсяг продажу має перевищувати \$1 млрд, частка іноземних активів має становити не менш як 25 \% загальної вартості активів компанії. 
Розвиток об'єднань підприємств

\begin{tabular}{|c|c|c|}
\hline Етап & Коротка характеристика & Приклади компаній \\
\hline $\begin{array}{c}\text { Етап I - } \\
\text { др. пол. XIX ст. }\end{array}$ & $\begin{array}{l}\text { Побудова горизонтальної інтеграції } \\
\text { (продаж однотипної продукції); початок } \\
\text { об’єднань підприємств у холдинги }\end{array}$ & $\begin{array}{l}\text { «New York, New Haven and } \\
\text { Hartford», «United States Steel», } \\
\text { «Standard Oil Company», } \\
\text { «American Tobacco Company» }\end{array}$ \\
\hline $\begin{array}{l}\text { Етап II - період } \\
\text { після Другої } \\
\text { світової війни }\end{array}$ & $\begin{array}{l}\text { Побудова вертикальної інтеграції } \\
\text { (розподіл виробництва) }\end{array}$ & $\begin{array}{l}\text { «Continental Can», «General } \\
\text { Electric», «General Motors» }\end{array}$ \\
\hline $\begin{array}{c}\text { Етап III - 60-ті рр. } \\
\text { ХХ ст. }\end{array}$ & Початок утворення конгломератів & «Paramount Communication» \\
\hline $\begin{array}{c}\text { Етап IV - 80-ті pp. } \\
\text { XX ст. }\end{array}$ & $\begin{array}{l}\text { Зростала необхідність продажу активів } \\
\text { компанії для продовження її діяльності; } \\
\text { організовувалися внутрішні банківські } \\
\text { операції при об'єднанні }\end{array}$ & «RJR Nabisco», «Drexel» \\
\hline $\begin{array}{c}\text { Етап V-90-ті рр. } \\
\text { XX ст. }\end{array}$ & $\begin{array}{l}\text { 3ріс попит на дешеві об’єкти промисловості; } \\
\text { 3’явилися нові правила списання гудвілу; } \\
\text { поширювалося державне регулювання на } \\
\text { більшість галузей промисловості }\end{array}$ & «CitiGroup» \\
\hline Етап VI - з 1998 p. & $\begin{array}{lrr}\text { Зменшення } & \text { національних } & \text { бар’єрів; } \\
\text { поширення } & \text { відслідковування } & \text { технологій; } \\
\text { початок ери мегаоб’єднань } & \end{array}$ & $\begin{array}{c}\text { «ationsBank/BankAmerica», } \\
\text { «Daimler/Crysler» }\end{array}$ \\
\hline
\end{tabular}

Сьогодні на діяльність транснаціональних корпорацій припадає понад 50 \% світового виробництва й понад 65 \% світової торгівлі та міжнародної міграції капіталу, тобто вплив транснаціональних корпорацій на світову економіку дуже великий. Прибутки від продажу продукції таких компаній часто перевищують бюджети навіть розвинених країн світу. Найбільші транснаціональні корпорації містяться в США (близько 150 великих компаній), Китаї (понад 100), Японії (60), Німеччині, Франції, Великій Британії (по 30), Південній Кореї (25), Швейцарії (17). Водночас останніми роками транснаціональні корпорації створюють і в країнах, що активно розвиваються, наприклад Індії та Мексиці.

Розвиток міжнародних корпорацій набув поширення внаслідок структурних, динамічних змін у світовій економіці XIX ст. Однак деякі фірми, що мають ознаки ТНК, з'явилися набагато раніше. Зокрема, англійська «East India Company» утворилася ще в 1600 р., деякі інші великі фірми також існують не одне століття, але особливо інтенсивно концентрація капіталу у сфері виробництва, торгівлі та банківсько-кредитній діяльності, яка стимулювала утворення ТНК, відбувалася $з$ другої третини XIX ст. У той час в організації економічної діяльності відбувалися важливі перетворення, основний зміст яких полягав у тому, що [1]:

1) у результаті промислової революції другої половини XIX ст., яка заклала підвалини масового та спеціалізованого виробництва, великі підприємства, комерційні структури здобули істотні переваги в господарській, конкурентній діяльності, що допомогло їм отримувати значно вищі прибутки;

2) особливо широко почав використовуватися принцип партнерства, який, базуючись на більш зручних та ефективних механізмах корпоративної відповідальності (порівняно з відповідальністю персональною), створював можливості для мобілізації коштів середніх і дрібних вкладників.

На сьогоднішній день ядром світової економічної системи являються понад 500 ТНК. Всього у світі діють приблизно 60 тис. фінансово-промислових груп і ТНК, що мають близько 250 тис. філіалів за межами країн базування. Під їх керівництвом відбувається контроль 50 \% світового промислового виробництва, проводяться понад 70 \% операцій торгівлі у світі, з них $40 \%$ - усередині ТНК (які відбуваються за трансфертними цінами, що формуються не під впливом ринку, а з урахування довгострокової політики материнської компанії), 80 \% патентів і ліцензій на нову техніку, технології і ноу-хау. Середньорічний обсяг продажу ТНК становить кілька сотень мільйонів доларів, понад 500 ТНК мають річний обсяг збуту понад 18 млрд доларів, а найбільші - сотні мільярдів доларів США. Вони реалізують 80 \% усієї виробленої продукції електроніки та хімії, 95 \% фармацевтики, 76 \% продукції машинобудування. Під контролем ТНК перебуває 90 \% світового ринку пшениці, кави, кукурудзи, лісоматеріалів, тютюну та залізної руди, 85 \% ринку міді и бокситів, 80 \% - ринку чаю та олова, 75 \% - сирої нафти, натурального каучуку та бананів [1].

Серед закордонних інвесторів найбільш інвестиційно-привабливими в Україні $є$ такі галузі економіки: харчова промисловість та переробка сільськогосподарських продуктів - 15,7 \% від загального обсягу ПЗІ, залучених до України; торгівля - 15,6 \%; фінансова сфера - 8,5 \%; машинобудування - 8,0 \%; транспорт - 7,6 \%; металургія та обробка металу - 5,4 \%; операції з нерухомістю - 4,6 \%; хімічна та нафтохімічна промисловість - 4,1\%. При цьому для ТНК із країн Свропейського Союзу та США найбільш 
привабливими $\epsilon$ : українська харчова промисловість, підприємства торгівлі, фінансовий сектор, фармацевтика [2]. За минулий рік Укргазвидобування отримало 55 млрд грн виручки й 12 млрд грн прибутків. Інший приклад - підприємства, які належать до сфери ритейлу. Наприклад, «Епіцентр» 3 оборотом 28 млрд грн. Він не монополіст на українському ринку, однак дуже потужний. Свого часу з'являлися повідомлення, що компанія планує вихід на ринок Грузії [3].

За підсумками першого півріччя 2017 р. найбільш привабливими секторами здійснення угод злиття i поглинання стали [4]:

- АПК (10 угод, у т. ч. одна угода 3 канадським інвестором);

- банківський сектор (4 угоди, аквізиторами є РФ, КНР, Казахстан та Кіпр);

- нафта та газ (3 угоди, у т. ч. одна угода з нідерландським інвестором);

- фінанси (серед 3 угод, одна - російська компанія-покупець).

У червні 2017 р. остаточно завершилася процедура продажу Українського банку реконструкції та розвитку китайській біржі Bohai Commodity. Вартість цієї угоди становила 82,83 млн дол. Відповідно до наявних даних про вартість угод, найбільш масштабною угодою М\&А було придбання Кернел активів компанії «Українські аграрні інвестиції» вартістю 155 млн дол. та 10 компаній, які входять до складу цього агрохолдингу за 43,3 млн дол [4].

Німецький фармацевтичний та агрохімічний велетень - концерн Bayer у вересні 2018 р. відкрив насіннєвий завод. Сума інвестицій у завод становила 200 мільйонів доларів. Новий завод забезпечить близько 85 постійних і 220 сезонних робочих місць для виробництва 750 тисяч посівних одиниць насіння кукурудзи щорічно [5].

Вчені з Вищої технічної школи Цюріха склали модель глобальної економіки, з допомогою якої змогли визначити 147 транснаціональних корпорацій, які контролюють 40 \% всього світового доходу. Науковці проаналізували взаємозв'язки 43 тисяч транснаціональних корпорацій та визначили, що існує відносно невелика група компаній, в основному банки, яка здійснює непропорційно великий вплив на світову економіку. Модель виявила ядро з 1318 компаній, які мали найбільше непрямих зв'язків 3 іншими підприємствами. Кожна 3 цих компаній була безпосередньо пов'язана 3 двома або кількома іншими, а ті в свою чергу так чи інакше брали участь у структурі власного капіталу ще в середньому 20 компаній. Хоча на ці 1318 компаній в сукупності припадає 20 \% світового доходу, вони через частки в акціонерному капіталі колективно володіють більшістю найбільших в світі компаній реального сектора економіки, на частку яких припадає ще 60 \% світового доходу. Коли науковці продовжили досліджувати глибше, 3'ясувалося, що ці 1318 компаній, зі свого боку, колективно належать 147 корпоративним монстрам. Корпорації зі «списку 147» контролюють 40 \% всього багатства в системі [6].

Основними факторами, які впливають на суб'єктів господарювання до укрупнення бізнесу є: отримання надійного постачальника факторів виробництва; зменшення ступеня ризику при виході на нові ринки збуту та їх розширенні; зменшення кількості конкурентів, придбання підприємств 3 однаковими галузями діяльності сприяє розширенню межі даної діяльності та зменшенню кількості конкурентів в ній; диверсифікація активів та діяльності з метою зменшення ризиків та підвищення потенціалу прибутковості діяльності підприємства; особисті мотиви вищої ланки керівництва.

У сучасних ринкових умовах підприємства прагнуть завоювати нові ринки і для розширення своєї діяльності обирають один зі способів об’єднання - приєднання, придбання або злиття.

Злиття підприємств $з$ метою досягнення міжнародної конкурентоспроможності є наразі актуальним для України, тому що наша держава прагне зайняти стійку позицію у світовій економіці, забезпечити стабільне економічне зростання та підтвердити статус країни з ринковою економікою.

Динаміку кількості різних форм господарського об'єднання підприємств, зареєстрованих в Єдиному державному реєстрі підприємств та організацій України (ЄДРПОУ), можна побачити за допомогою статистичної інформації Державної служби статистики України (табл. 2).

Таблиия 2

Кількість суб'єктів СДРПОУ за організаџійно-правовими формами господарювання за 2011-2019 рр.

(дані взято на початок року)

\begin{tabular}{|c|c|c|c|c|c|c|c|c|}
\hline \multirow{2}{*}{ Назва суб'єкта } & \multicolumn{9}{|c|}{ Рік } \\
\cline { 2 - 10 } & 2011 & 2013 & 2014 & 2015 & 2016 & 2017 & 2018 & 2019 \\
\hline Асоціація & 2172 & 2246 & 2290 & 2203 & 2260 & 2331 & 2376 & 2433 \\
\hline Корпорація & 637 & 618 & 604 & 565 & 560 & 564 & 558 & 558 \\
\hline Консорціум & 62 & 65 & 66 & 64 & 66 & 69 & 74 & 75 \\
\hline Концерн & 238 & 216 & 210 & 193 & 195 & 195 & 191 & 187 \\
\hline $\begin{array}{l}\text { Інші об'єднання } \\
\text { юридичних осіб }\end{array}$ & 1015 & 875 & 833 & 763 & 756 & 767 & 753 & 744 \\
\hline Разом & 4124 & 4020 & 4003 & 3788 & 3837 & 3926 & 3952 & 3997 \\
\hline
\end{tabular}


Аналізуючи статистичні дані, ми побачили, що загальна кількість об'єднань підприємств в Україні щорічно збільшується, починаючи 32015 р. До 2015 р. тенденція мала протилежний характер зменшувалася кількість об'єднань за рахунок зменшення таких складових, як корпорація, концерн та інші об'єднання. Збільшення кількості об'єднань підприємств спостерігається за такою організаційноправовою формою, як асоціація. Так у 2019 р. кількість досліджених суб'єктів господарювання становила 3997 одиниць, що на 5 \% більше, порівняно з 2015 р. [8].

Тенденцію щорічного зростання кількості різних форм господарського об'єднання підприємств можна прокоментувати двояко. По-перше, вона може дійсно свідчити про те, що сучасні підприємства мають економічну потребу в об’єднанні своїх фінансових, виробничих, інвестиційних, організаційних та інших видів ресурсів для спільного вирішення соціально-економічних проблем. По-друге, відбувається перетворення окремих, раніше самостійних суб'єктів господарювання на структурний підрозділ великого підприємства 3 непередбаченими наслідками (наприклад, концентрація капіталу в руках крупних власників і кабальна залежність від чужого капіталу) $[9,10]$.

Висновки та перспективи подальших досліджень. Отже, сучасні підприємства мають економічну потребу в об’єднанні своїх фінансових, виробничих, інвестиційних, організаційних та інших видів ресурсів для спільного вирішення проблем. Створення об'єднання підприємств забезпечує його учасників стратегічними перевагами над конкурентами (додатковими ресурсами, можливостями впровадження результатів наукових досліджень), також дозволяє координувати діяльність всіх ланок технологічного ланцюга та залучати великі фінансові ресурси.

Таким чином, проаналізувавши тенденції, які діють на ринку України, можна зробити висновок, що ключовими силами у конкурентній боротьбі є знання та інновації. Ефективність функціонування будьякого суб'єкта господарювання залежить від його розмірів, від інноваційної діяльності. Щоб забезпечити позитивні зміни щодо конкурентоспроможності, фінансового стану та підвищення потенціалу, одним із дієвих інструментів є об'єднання підприємств. Подальші наші дослідження будуть спрямовані на вивчення особливостей бухгалтерського обліку фінансових результатів об'єднань підприємств.

\section{Список використаної літератури:}

1. Охріменко О.О. Транснаціональні корпорації у системі світових економічних відносин / О.О. Охріменко, Д.Д. Сільвестрова // Ефективна економіка. - 2013. - № 5 [Електронний ресурс]. - Режим доступу : http://www.economy.nayka.com.ua/?op=1\&z=2054.

2. Федоров Б.Т. Новый англо-русский банковский и экономический словарь / Б.Т. Федоров. - СПб. : ЛимбусПресс, 2000. -838 c.

3. Мельничук В. Шлях гігантів / В.Мельничук // Тиждень.UА. - 2018. - 15 січ. [Електронний ресурс]. - Режим доступу : https://tyzhden.ua/Economics/207431.

4. Підсумки I півріччя 2017-го. АПК лідирує в злиттях і поглинаннях [Електронний ресурс]. - Режим доступу : http://propozitsiya.com/ua/pidsumky-i-pivrichchya-2017-go-apk-lidyruye-v-zlyttyah-i-poglynannyah.

5. Губар О. Вауеr вклав 200 мільйонів доларів у новий завод в Україні / О.Губар // Deutsche Welle. - 2018 [Електронний ресурс]. - Режим доступу : https://p.dw.com/p/34N7u.

6. Визначено 147 корпорацій, які керують усім світом / Редакція ТСН [Електронний ресурс]. - Режим доступу : https://tsn.ua/groshi/viznacheno-147-korporaciy-yaki-keruyut-usim-svitom.html.

7. Кількість юридичних осіб за організаційними формами / Головне управління статистики : офіційна сторінка. - Київ [Електронний ресурс]. http://www.kiev.ukrstat.gov.ua/p.php3?c=950\&lang=1.

8. Дзюба С.Г. Монопольний характер організаційно-правових форм об'єднання підприємств / С.Г. Дзюба // Зовнішня торгівля : економіка, фінанси, право. - 2012. - № 2. - С. 109-119.

9. Audretson D. Innovative Clusters and the Industry Life Cycle / D.Audretson, M.Feidman. - M. : Center for Economic Policy Research, 1998. - № 1161 [Electronic Resourse]. - Access mode : http://citeseerx.ist.psu.edu/viewdoc/download?doi=10.1.1.684.6613\&rep=rep1\&type=pdf.

10. Chandler A.D. The Visible Hand: The Managerial Revolution in American Business / A.D. Chandler. - Cambridge, Mass. : Belknapp Press, 1977. - 249 p. [Electronic Resourse]. - Access mode : https://dipiufabc.files.wordpress.com/2015/06/alfred_d-_chandler_the_visible_hand_managerial_bookzz-org.pdf.

\section{References:}

1. Ohrimenko, O.O. and Sil'vestrova, D.D. (2013), «Transnacional'ni korporacii' u systemi svitovyh ekonomichnyh vidnosyn», Efektyvna ekonomika, No. 5, [Online], available at: http://www.economy.nayka.com.ua/?op=1\&z=2054

2. Fedorov, B.T. (2000), Novyj anglo-russkij bankovskij i jekonomicheskij slovar', Sankt Peterburg, 848 p.

3. Mel'nychuk, V. (2018), «Shljah gigantiv», Tyzhden'.UA, 15 sich., [Online], available at: https://tyzhden.ua/Economics/207431

4. «Pidsumky I pivrichchja 2017-go. APK lidyruje v zlyttjah i poglynannjah», [Online], available at: http://propozitsiya.com/ua/pidsumky-i-pivrichchya-2017-go-apk-lidyruye-v-zlyttyah-i-poglynannyah

5. Gubar, O. (2018), «Bayer vklav 200 mil'joniv dolariv u novyj zavod v Ukrai'ni», Deutsche Welle, [Online], available at: https://p.dw.com/p/34N7u 
6. «Vyznacheno 147 korporacij, jaki kerujut' usim svitom», Redakcija TSN, [Online], available at: https://tsn.ua/groshi/viznacheno-147-korporaciy-yaki-keruyut-usim-svitom.html

7. Golovne upravlinnja statystyky (2019), Kil'kist' jurydychnyh osib za organizacijnymy formamy, Kyi'v, [Online], available at: http://www.kiev.ukrstat.gov.ua/p.php3?c=950\&lang=1

8. Dzjuba, S.G. (2012), «Monopol'nyj harakter organizacijno-pravovyh form ob'jednannja pidpryjemstv», Zovnishnja torgivlja: ekonomika, finansy, pravo, No. 2, pp. 109-119.

9. Audretson, D. and Feidman, M. (1998), «Innovative Clusters and the Industry Life Cycle», Center for Economic Policy Research, M., No. 1Online], available at: http://citeseerx.ist.psu.edu/viewdoc/download?doi=10.1.1.684.6613\&rep=rep1\&type=pdf

10. Chandler, Alfred, D. (1977), The Visible Hand: The Managerial Revolution in American Business, Belknapp Press, Mass., Cambridge, 249 p., [Online], available at: https://dipiufabc.files.wordpress.com/2015/06/alfred_d_chandler_the_visible_hand_managerial_bookzz-org.pdf

Авдалян Катерина Вікторівна - аспірант 3-го року навчання спеціальності 071 «Облік і оподаткування» кафедри фінансів, обліку і оподаткування ДВНЗ «Переяслав-Хмельницький державний педагогічний університет імені Григорія Сковороди».

Наукові інтереси:

- облік фінансових результатів об'єднань підприємств;

- методологія наукових досліджень в бухгалтерському обліку.

E-mail: katya.tereshhenko.93@mail.ru.

orcid.org/0000-0002-3605-4997

Стаття надійшла до редакції 08.10.2019. 